\title{
Hydrogen sulfide protects PC12 cells against reactive oxygen species and extracellular signal-regulated kinase 1/2-mediated downregulation of glutamate transporter-1 expression induced by chemical hypoxia
}

\author{
LIANGCAN XIAO $^{1 *}$, AIPING LAN $^{2 *}$, LIQIU MO $^{1}$, WENMING XU ${ }^{3}$, NAN JIANG $^{1}$, \\ FEN HU $^{2}$, JIANQIANG FENG ${ }^{2}$ and CHANGRAN ZHANG ${ }^{3}$
}

\begin{abstract}
${ }^{1}$ Department of Anesthesiology, The First Affiliated Hospital, Sun Yat-Sen University, Guangzhou; ${ }^{2}$ Department of Physiology, Zhongshan School of Medicine, Sun Yat-Sen University, Guangzhou; ${ }^{3}$ Department of Internal Medicine, Region of Huangpu, The First Affiliated Hospital, Sun Yat-Sen University, Guangzhou, Guangdong, P.R. China
\end{abstract}

Received May 9, 2012; Accepted June 28, 2012

DOI: $10.3892 /$ ijmm.2012.1090

\begin{abstract}
Hypoxia and/or ischemia are implicated in neurodegenerative disorders. In these diseases, hypoxia/ischemia may induce oxidative stress, including production of reactive oxygen species (ROS), which result in a decrease in glutamate transporter expression. Hydrogen sulfide $\left(\mathrm{H}_{2} \mathrm{~S}\right)$, as the third gasotransmitter, has neuroprotective effects and potent antioxidant properties. In the present study, we investigated the role of glutamate transporter-1 (GLT-1) in the protection of $\mathrm{H}_{2} \mathrm{~S}$ against chemical hypoxia-induced injury in $\mathrm{PC} 12$ cells. We found that cobalt chloride $\left(\mathrm{CoCl}_{2}\right)$, a chemical hypoxia agent, reduced the expression of GLT-1 in a time-dependent manner. Pretreatment with NaHS (a donor of $\mathrm{H}_{2} \mathrm{~S}$ ) reversed the $\mathrm{CoCl}_{2}$-induced downregulation of GLT-1 expression. Pretreatment with DHK (a selective inhibitor of GLT-1) for 30 min prior to NaHS preconditioning significantly inhibited the cytoprotection of $\mathrm{H}_{2} \mathrm{~S}$ against $\mathrm{CoCl}_{2}$-induced injuries, leading to an increase in cytotoxicity and apoptosis as well as to a loss of mitochondrial membrane potential (MMP). In addition, we found that similar to the effect of NaHS, pretreatment with NAC (a ROS scavenger) or U0126 (a MEK1/2 inhibitor)
\end{abstract}

Correspondence to: Professor Jianqiang Feng, Department of Physiology, Zhongshan School of Medicine, Sun Yat-Sen University, 74 Zhongshan 2nd Road, Guangzhou, Guangdong 510080, P.R. China E-mail: fengjq-sums@163.com

Professor Changran Zhang, Department of Internal Medicine, Region of Huangpu, The First Affiliated Hospital, Sun Yat-Sen University, Guangzhou, Guangdong 510700, P.R. China

E-mail: zhcr2303@sina.com

*Contributed equally

Key words: chemical hypoxia, hydrogen sulfide, glutamate transporter-1, apoptosis, oxidative stress blocked the downregulation of GLT-1 expression induced by $\mathrm{CoCl}_{2}$. Collectively, we demonstrated for the first time that ROS and extracellular signal-regulated kinase 1/2 (ERK1/2)mediated reduction of GLT-1 expression may be involved in chemical hypoxia-induced neural injury and that $\mathrm{H}_{2} \mathrm{~S}$ attenuates this injury partly by upregulating GLT-1 expression in PC12 cells.

\section{Introduction}

It is well documented that hypoxia and/or ischemia can elicit the release of several neurotransmitters $(1,2)$, including glutamate (3). Such elevated levels of glutamate, and the subsequent activation of ionotropic NMDA receptors, can trigger the neuronal damage during hypoxia and/or ischemia $(4,5)$. Glutamate homeostasis is therefore crucial to prevent neuronal death after a hypoxic/ischemic episode. Glutamate transport is the only mechanism for the removal of glutamate from the extracellular fluid in the brain $(6,7)$, and it is essential for maintaining extracellular glutamate below neurotoxic levels in the normal brain (8). Therefore, glutamate transporters are considered to play a key role in the process of increase in extracellular glutamate during hypoxia/ischemia.

To date, 5 distinguishing high-affinity, $\mathrm{Na}^{+}$-dependent glutamate transporters have been identified: excitatory amino acid transporter (EAAT)1, glutamate-aspartate transporter (GLAST), EAAT2, glutamate transporter-1 (GLT-1), EAAT3, excitatory amino acid carrier 1 (EAAC1), EAAT4 and EAAT5. These transporters are present throughout the central nervous system (CNS), with GLT-1 being highly abundant in astroglial cells, whereas GLAST exists at higher levels in Bergmann glia in the cerebellum $(9,10)$. GLT-1 plays a critical role in CNS homeostasis, accounting for up to $70 \%$ of glutamate clearance $(10,11)$.

The roles of GLT-1 in hypoxia/ischemia-induced injury and neuroprotection have attracted extensive attention. However, the findings are controversial. A pharmacological study indicated that the GLT-1 blocker reduces the ischemia- 
induced glutamate release in rat cortical superfusates (12), revealing that GLT-1 releases glutamate during ischemia. By contrast, Rao et al (13) reported that the antisense knockdown of GLT-1 exacerbates ischemia-triggered neuronal damage in the rat brain, suggesting that GLT-1 takes up glutamate to protect neurons during ischemia. In addition, ischemic preconditioning upregulates the GLT-1 protein which may play a role in the neuroprotective mechanism of preconditioning (14). In neonatal rats, it was shown that the neuroprotection of ceftriaxone preconditioning against hypoxia/ischemia-induced neuronal injury is associated with upregulation of GLT-1 expression (15). On the other hand, an association between change in GLT-1 expression and hypoxia/ischemia has been reported by several studies $(16,17)$. Raghavendra et al (16) observed that the expression of GLT-1 is reduced following transient global ischemia. Conversely, chronic hypoxia upregulates the expression of EAAC1 and GLT-1, but not GLAST (17). These findings support the theory that GLT-1 has a complicated function (cytoprotective vs. cytotoxic effects) after hypoxic/ischemic episodes. Thus, it is necessary to explore the roles of GLT-1 in neuronal injury or the neuroprotective effects in different hypoxic/ischemic models.

Hydrogen sulfide $\left(\mathrm{H}_{2} \mathrm{~S}\right)$, recently considered a novel neuromodulator in the CNS, has been shown to protect astrocytes against $\mathrm{H}_{2} \mathrm{O}_{2}$-induced neural damage by enhancing glutamate uptake (18), suggesting an impact of $\mathrm{H}_{2} \mathrm{~S}$ on glutamate transporters. We have also demonstrated that $\mathrm{H}_{2} \mathrm{~S}$ protects $\mathrm{PC} 12$ cells against chemical hypoxia-induced injury by inhibiting reactive oxygen species (ROS) overproduction, extracellular signalregulated kinase $1 / 2(E R K 1 / 2)$ and the p38 mitogen-activated protein kinase (MAPK) signaling pathways $(19,20)$. Since it is reported that ROS and the activation of the ERK1/2 pathway are involved in the downregulation of GLT-1 protein expression induced by $\mathrm{H}_{2} \mathrm{O}_{2}$ or amyloid- $\beta$ (A $\left.\beta\right)$ in astrocytes $(19,21)$, we hypothesized that ROS and ERK1/2-mediated downregulation of GLT-1 might be implicated in chemical hypoxia-induced neuronal injury and that $\mathrm{H}_{2} \mathrm{~S}$ might confer neuroprotection by enhancing GLT-1 expression. To test this hypothesis, PC12 cells, which are derived from chromafin cells of the adrenal medulla, were exposed to cobalt chloride $\left(\mathrm{CoCl}_{2}\right)$, a well-known hypoxia mimetic agent, to establish a model of chemical hypoxia injury. The effects of $\mathrm{CoCl}_{2}$ and pretreatment with NaHS (a donor of $\mathrm{H}_{2} \mathrm{~S}$ ) on GLT-1 expression were observed. We found that: i) $\mathrm{CoCl}_{2}$ significantly inhibits the expression of GLT-1, ROS and the ERK1/2 pathway contribute to this inhibitory effect; ii) NaHS pretreatment clearly attenuates the inhibitory effect of $\mathrm{CoCl}_{2}$ on GLT-1 expression; iii) DHK, a selective inhibitor of GLT-1, blocks the neuroprotection of $\mathrm{H}_{2} \mathrm{~S}$ against $\mathrm{CoCl}_{2}-$ induced injury in PC12 cells.

\section{Materials and methods}

Materials. NaHS, $\mathrm{CoCl}_{2}, \mathrm{~N}$-acetyl-L-cysteine (NAC), Hoechst 33258, propidium iodide (PI), RNase and Rhodamine 123 (Rh123) were purchased from Sigma-Aldrich (St. Louis, MO, USA). The cell counter kit-8 (CCK-8) was purchased from Dojindo Laboratories (Kumamoto, Japan). The DMEM medium and fetal bovine serum (FBS) were supplied by Gibco-BRL (Grand Island, NY, USA). Anti-GLT-1 antibody was purchased from Abcam (Cambridge, UK). DHK was purchased from Merck Co. Anti- $\beta$-actin antibody, horseradish peroxidase (HRP)-conjugated secondary antibody and the BCA protein assay kit were purchased from KangChen Bio-tech, Inc. (Shanghai, China). Enhanced chemiluminescence (ECL) solution was purchased from Nanjing KeyGen Biotech Co., Inc. (Nanjing, China).

Cell culture and treatments. The rat pheochromocytoma cell line PC12 cells were purchased from the Sun Yat-Sen University Experimental Animal Center, and were grown in DMEM medium supplemented with $10 \% \mathrm{FBS}$ at $37^{\circ} \mathrm{C}$ under an atmosphere of $5 \% \mathrm{CO}_{2}$ and $95 \%$ air. According to our previous study (20), chemical hypoxia was achieved by adding $\mathrm{CoCl}_{2}$ at $600 \mu \mathrm{M}$ into the medium and cells were incubated in the presence of $\mathrm{CoCl}_{2}$ for the indicated times. The cytoprotective effects of $\mathrm{H}_{2} \mathrm{~S}$ were observed by administering $400 \mu \mathrm{M}$ NaHS (a donor of $\mathrm{H}_{2} \mathrm{~S}$ ) for $30 \mathrm{~min}$ prior to exposure to $\mathrm{CoCl}_{2}$ for $24 \mathrm{~h}$. NAC (a scavenger of ROS) or U0126 (a MEK1/2 inhibitor) was administered 60 or 120 min prior to exposure of the PC12 cells to $600 \mu \mathrm{M} \mathrm{CoCl}_{2}$ for $24 \mathrm{~h}$.

Cell viability assay. The CCK- 8 assay was employed to investigate the cell viability of PC12 cells cultured in 96-well plates. After the indicated treatments, $10 \mu \mathrm{l} \mathrm{CCK-8}$ solution was added to each well of the plate and the cells in the plate were incubated for $4 \mathrm{~h}$ in the incubator. The absorbance at $450 \mathrm{~nm}$ was measured with a microplate reader (Molecular Devices, Sunnyvale, CA, USA). Means of 4 well optical density (OD) in the indicated groups were used to calculate the percentage of cell viability according to the formula below: Percentage of cell viability $(\%)=\left(\mathrm{OD}_{\text {treatment group }} / \mathrm{OD}_{\text {control group }}\right) \times 100 \%$. The experiment was repeated 3 times.

Nuclear staining for assessment of apoptosis with Hoechst 33258. Morphological changes, such as chromosomal condensation and fragmentation in the nuclei of PC12 cells, were observed by Hoechst 33258 staining followed by photofluorography. Cells were plated at a density of $1 \times 10^{6}$ cells/well in $35 \mathrm{~mm}$ dishes. Cells were preconditioned with $400 \mu \mathrm{M}$ NaHS for $30 \mathrm{~min}$, and subsequently exposed to $600 \mu \mathrm{M}$ $\mathrm{CoCl}_{2}$ for $48 \mathrm{~h}$. To test the role of GLT-1 in $\mathrm{H}_{2} \mathrm{~S}$-induced cytoprotection against chemical hypoxia-induced apoptosis, cells were treated with the GLT-1 inhibitor DHK for $30 \mathrm{~min}$ prior to preconditioning with NaHS. At the end of the indicated treatments, cells were harvested and fixed with $4 \%$ paraformaldehyde in $0.1 \mathrm{~mol} / 1$ phosphate-buffered saline (PBS, pH 7.4) for $10 \mathrm{~min}$. After rinsing with PBS, the nuclear DNA was stained with $5 \mathrm{mg} / \mathrm{ml}$ Hoechst 33258 solution for 10 min before being rinsed briefly with PBS and then visualized under a fluorescence microscope (Bx50-FLA; Olympus, Tokyo, Japan). Viable cells displayed a uniform blue fluorescence throughout the nucleus, whereas apoptotic cells showed condensed and fragmented nuclei.

Flow cytometric analysis of apoptosis. Treated PC12 cells were digested with trypsin $(2.5 \mathrm{mg} / \mathrm{ml})$, centrifuged at $350 \mathrm{x} \mathrm{g}$ for $10 \mathrm{~min}$ and the supernatant was removed. Cells were washed twice with PBS and fixed with $70 \%$ ice-cold ethanol. Cells were then centrifuged at $350 \mathrm{x} \mathrm{g}$ for $10 \mathrm{~min}$, washed twice with PBS and adjusted to a concentration of 
$1 \times 10^{6}$ cells $/ \mathrm{ml}$. Subsequently, $0.5 \mathrm{ml}$ RNase $(1 \mathrm{mg} / \mathrm{ml}$ in PBS) was added to a $0.5 \mathrm{ml}$ cell sample. After gentle mixing with PI (at a terminal concentration of $50 \mathrm{mg} / \mathrm{l}$ ), mixed cells were filtered and incubated in the dark at $4^{\circ} \mathrm{C}$ for 30 min before flow cytometric analysis (FCM). The PI fluorescence of individual nuclei was measured by a flow cytometer (Beckman-Coulter, Los Angeles, CA, USA). Excitation, $488 \mathrm{~nm}$; emission, $615 \mathrm{~nm}$. The research software matched with FCM was used to analyze all the data of DNA labeling. In the DNA histogram, the amplitude of the sub-G1 DNA peak, which is lower than the G1 DNA peak, represents the number of apoptotic cells. The experiment was repeated 3 times.

Measurement of MMP. Mitochondrial membrane potential (MMP) was monitored using the fluorescent dye Rh123, a cell-permeable cationic dye that preferentially enters into the mitochondria based on the highly negative MMP. Depolarization of MMP results in loss of Rh123 from the mitochondria and a decrease in intracellular fluorescence. In the present study, PC12 cells were cultured in 24-well plates and treated with $400 \mu \mathrm{M}$ NaHS for 30 min prior to the administration of $600 \mu \mathrm{M} \mathrm{CoCl}_{2}$ for $24 \mathrm{~h}$. DHK was administered 30 min prior to NaHS preconditioning. To evaluate MMP, $\mathrm{Rh} 123(100 \mu \mathrm{g} / \mathrm{l})$ was added to cell cultures for $45 \mathrm{~min}$ at $37^{\circ} \mathrm{C}$ and fluorescence was measured over the entire field of vision using a fluorescent microscope connected to an imaging system (BX50-FLA; Olympus). The mean fluorescence intensity (MFI) of Rh123 from 5 random fields was analyzed using ImageJ 1.410 software (National Institutes of Health, Bethesda, MD, USA), and the MFI was taken as an index of the MMP. The experiment was repeated 3 times.

Western blot assay for protein expression. After the cells were subjected to the indicated treatments, they were harvested and lysed with cell lysis solution. Total protein in the cell lysate was quantified using the BCA protein assay kit. Sample buffer was added to cytosolic extracts, and after boiling for 5 min, equal amounts of supernatant from each sample were fractionated by $10 \%$ sodium dodecyl sulphate-polyacrylamide gel electrophoresis (SDS-PAGE). Total protein in the gel was transferred into polyvinylidene difluoride (PVDF) membranes. Membranes were blocked for $1.5 \mathrm{~h}$ at room temperature in fresh blocking buffer $[0.1 \%$ Tween-20 in Trisbuffered saline (TBS-T) containing 5\% fat-free milk] and then incubated with either anti-GLT-1 (1:2,500 dilution), or anti- $\beta$-actin antibodies (1:5,000 dilution) in freshly prepared TBS-T with 3\% free-fat milk overnight with gentle agitation at $4^{\circ} \mathrm{C}$. After 3 washes with TBS-T, membranes were incubated with HRP-conjugated goat anti-rabbit secondary antibodies (1:3,000 dilution; KangChen Bio-tech, Inc.) in TBS-T with 3\% fat-free milk for $1.5 \mathrm{~h}$ at room temperature. Membranes were washed 3 times with TBS-T, developed in ECL solution and visualized with X-ray film. Each experiment was repeated at least 3 times. For quantification, the film were scanned and analyzed using ImageJ 1.410 software. The density of specific bands was measured and normalized with the bands of Action. The experiment was repeated 3 times.

Statistical analysis. Data are representative of experiments performed in triplicate and are expressed as the mean $\pm \mathrm{SE}$.
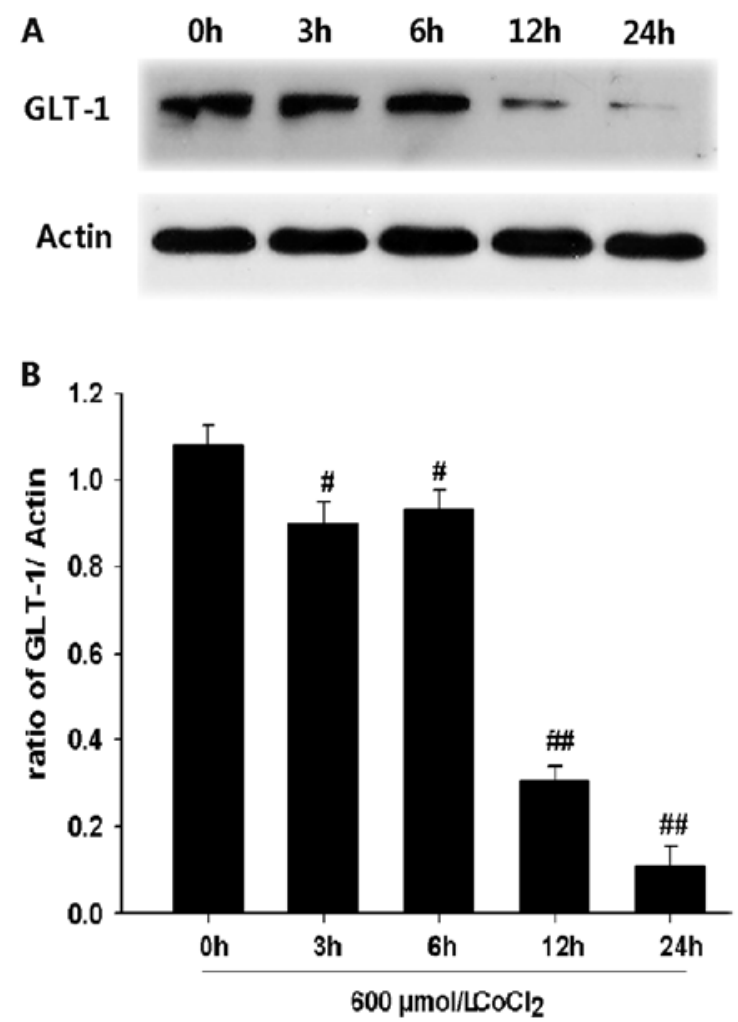

Figure 1. $\mathrm{CoCl}_{2}$ induces downregulation of GLT-1 expression in PC12 cells in a time-dependent manner. (A) Time course for the effects of $\mathrm{CoCl}_{2}$ on the expression of GLT-1 detected by western blot analysis. (B) Densitometric analysis for the results in (A). ${ }^{\#} \mathrm{P}<0.05,{ }^{\# \#} \mathrm{P}<0.01$ vs. the control group.

Differences between groups were analyzed by one-way analysis of variance (ANOVA) using SPSS 13.0 software, followed by the LSD post hoc comparison test. $\mathrm{P}<0.05$ was considered to indicate statistically significant differences.

\section{Results}

$\mathrm{CoCl}_{2}$ reduces the level of GLT-1 expression in PC12 cells. In order to explore the effect of $\mathrm{CoCl}_{2}$ on the GLT-1 expression level in PC12 cells, $\mathrm{PC} 12$ cells were exposed to $600 \mu \mathrm{M} \mathrm{CoCl}_{2}$ for the indicated times (i.e., 3, 6, 12 and $24 \mathrm{~h}$ ). Western blot analysis revealed that treatment with $600 \mu \mathrm{M} \mathrm{CoCl}_{2}$ caused downregulation of GLT-1 expression in a time-dependent manner (Fig. 1). These data indicate that chemical hypoxia may reduce GLT-1 protein levels in PC12 cells.

$\mathrm{H}_{2} \mathrm{~S}$ reverses $\mathrm{CoCl}_{2}$-induced downregulation of GLT-1 expression in PC12 cells. After PC12 cells were exposed to $600 \mu \mathrm{M}$ $\mathrm{CoCl}_{2}$ for $24 \mathrm{~h}$, the levels of GLT-1 protein expression were markedly decreased (Fig. 2). However, pretreatment of PC12 cells with $400 \mu \mathrm{M}$ NaHS for 30 min before exposure to $\mathrm{CoCl}_{2}$ reversed this effect, suggesting that NaHS preconditioning may enhance GLT-1 protein expression level in $\mathrm{CoCl}_{2}$-treated PC12 cells.

GLT-1 is involved in the cytoprotection of $\mathrm{H}_{2} \mathrm{~S}$ against $\mathrm{CoCl}_{2}-$ induced injury. To explore whether GLT-1 is involved in the cytoprotection of $\mathrm{H}_{2} \mathrm{~S}$ against $\mathrm{CoCl}_{2}$-induced injuries, $\mathrm{PC} 12$ cells were pretreated with DHK (a inhibitor of GLT-1) at 


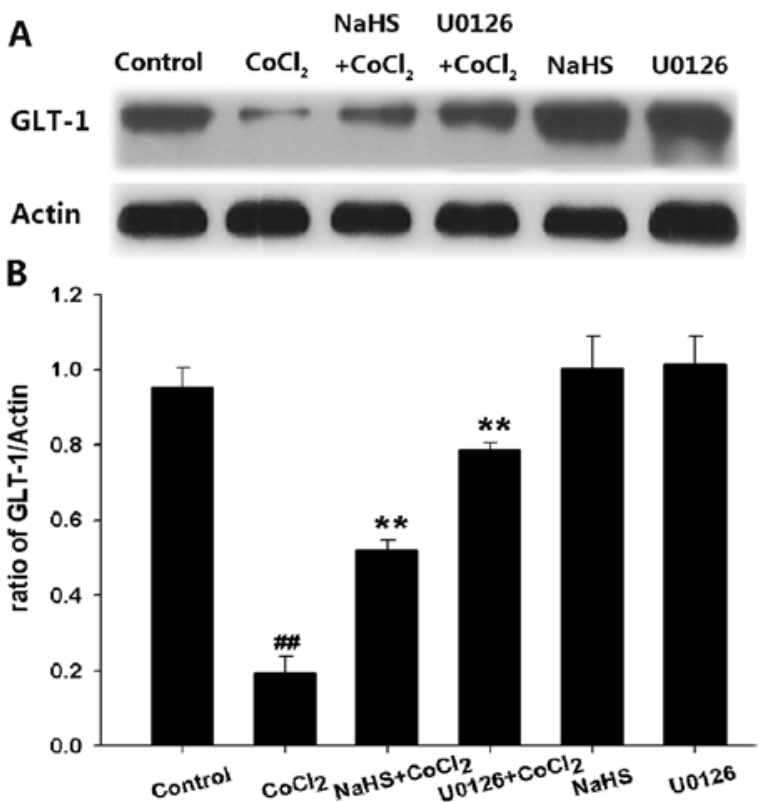

Figure 2. Effects of $\mathrm{H}_{2} \mathrm{~S}$ and U0126 on the downregulation of GLT-1 expression induced by $\mathrm{CoCl}_{2}$ in $\mathrm{PC} 12$ cells. (A) $\mathrm{PC} 12$ cells were treated with $600 \mu \mathrm{M} \mathrm{CoCl}_{2}$ for $24 \mathrm{~h}$ in the presence or absence of pretreatment with $400 \mu \mathrm{M}$ NaHS for $30 \mathrm{~min}$ or $10 \mu \mathrm{M} \mathrm{U} 0126$, an inhibitor of MEK1/2, for 120 min. (B) Densitometric analysis for the results in (A). ${ }^{\# \#} \mathrm{P}<0.01$ vs. the control group; ${ }^{* *} \mathrm{P}<0.01$ vs. the $\mathrm{CoCl}_{2}$ group.

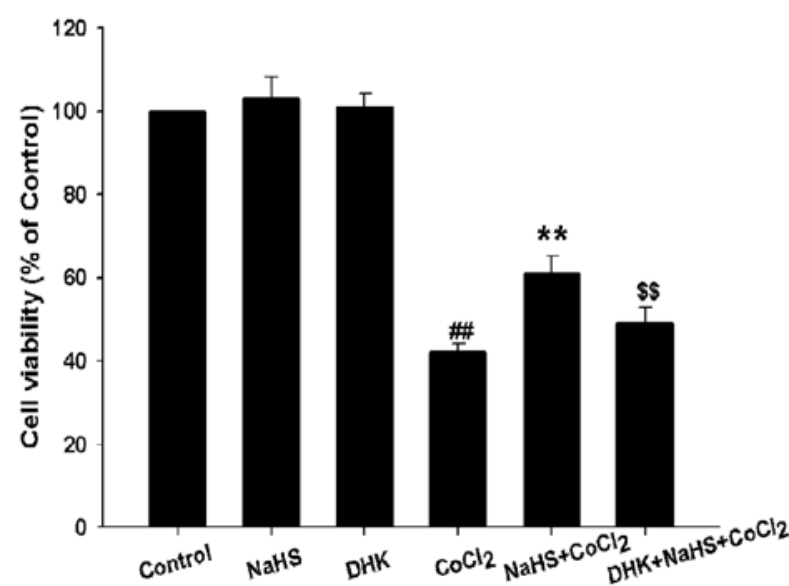

Figure 3. Role of GLT-1 in the cytoprotection of $\mathrm{H}_{2} \mathrm{~S}$ against the cytotoxicity induced by $\mathrm{CoCl}_{2}$ in $\mathrm{PC} 12$ cells. PC12 cells were treated with $600 \mu \mathrm{M} \mathrm{CoCl}_{2}$ for $24 \mathrm{~h}$ in the presence or absence of pretreatment with $400 \mu \mathrm{M} \mathrm{NaHS}$ for $30 \mathrm{~min}$ To inhibit GLT-1, cells were pretreated with DHK for $30 \mathrm{~min}$ before pretreatment with $400 \mu \mathrm{M} \mathrm{NaHS}$ followed by exposure to $600 \mu \mathrm{M} \mathrm{CoCl}_{2}$ for $24 \mathrm{~h}$. The CCK-8 assay was performed to detect cell viability. ${ }^{\# \prime} \mathrm{P}<0.01$ vs. the control group; ${ }^{* *} \mathrm{P}<0.01$ vs. the $\mathrm{CoCl}_{2}$ group; ${ }^{\$ \$} \mathrm{P}<0.01$ vs. the $\mathrm{NaHS}+\mathrm{CoCl}_{2}$ group.

$400 \mu \mathrm{M}$ for 30 min prior to NaHS preconditioning followed by exposure to $600 \mu \mathrm{M} \mathrm{CoCl}_{2}$ for $24 \mathrm{~h}$. As shown in Fig. 3, DHK pretreatment significantly blocked the protection of NaHS preconditioning against $\mathrm{CoCl}_{2}$-induced cytotoxicity, the cell viability was considerably decreased, from $62 \pm 2.3 \%$ to $50 \pm 2.1 \%(\mathrm{P}<0.01)$ (Fig. 3). Moreover, pretreatment with $400 \mu \mathrm{M}$ DHK also markedly inhibited $\mathrm{H}_{2} \mathrm{~S}$-induced antiapoptotic effects, increasing the number of apoptotic cells with nuclear condensation and fragmentation (Fig. 4A) as

\section{A}

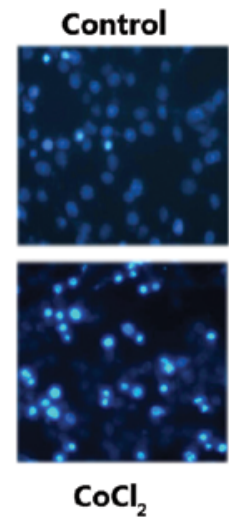

B
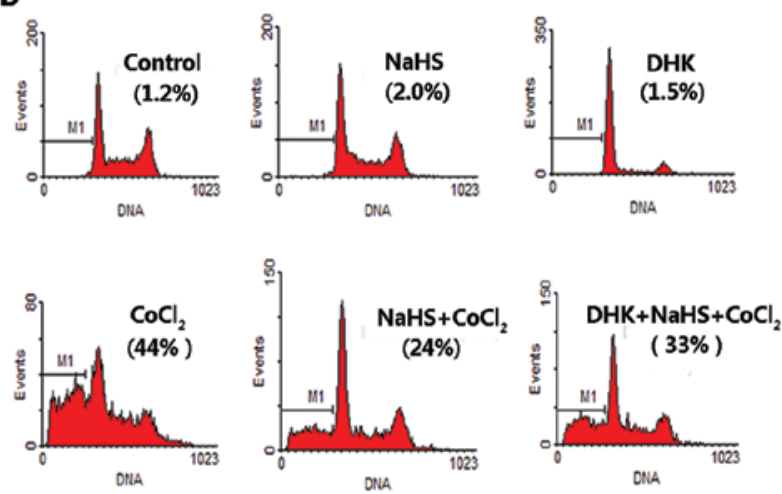

C

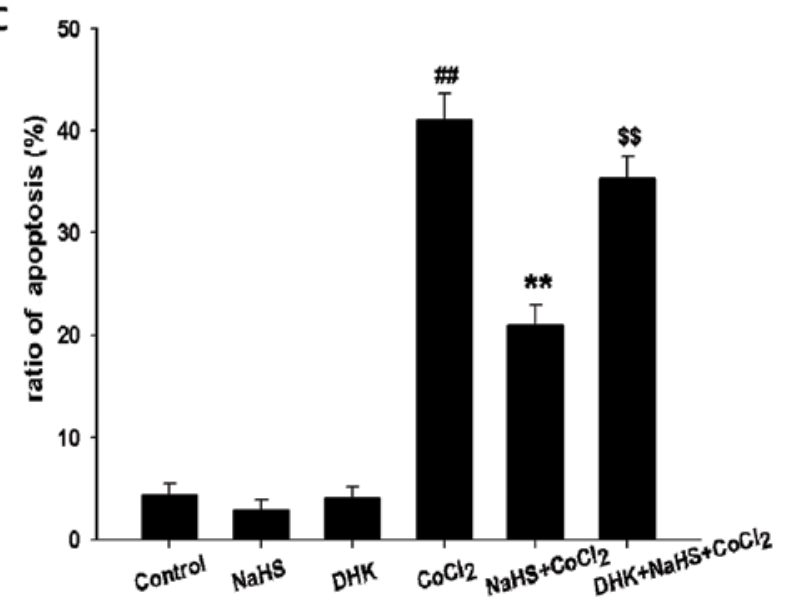

Figure 4. Role of GLT-1 in the cytoprotection of $\mathrm{H}_{2} \mathrm{~S}$ against apoptosis induced by $\mathrm{CoCl}_{2}$ in PC12 cells. (A) Morphological changes in apoptotic PC12 cells assessed by Hoechst 33258 staining. (B) Apoptosis percentage of PC12 cells was determined by flow cytometry (FCM) as described in Materials and methods. (C) The statistical results of the FCM analysis for the apoptosis of the PC12 cells. Control group, normal PC12 cells; NaHS group, cells were treated with $400 \mu \mathrm{M} \mathrm{NaHS}$ for $30 \mathrm{~min}$ alone; DHK group, cells were treated with $400 \mu \mathrm{M}$ DHK for 30 min alone; $\mathrm{CoCl}_{2}$ group, cells were treated with $600 \mu \mathrm{M} \mathrm{CoCl}_{2}$ for $48 \mathrm{~h}$; $\mathrm{NaHS}+\mathrm{CoCl}_{2}$ group, cells were preconditioned with $400 \mu \mathrm{M}$ NaHS for 30 min followed by exposure to $600 \mu \mathrm{M} \mathrm{CoCl}_{2}$ for $48 \mathrm{~h}$. DHK $+\mathrm{NaHS}+\mathrm{CoCl}_{2}$ group, cells were pretreated with $400 \mu \mathrm{M}$ DHK for 30 min prior to NaHS preconditioning followed by the same protocols as in the NaHS $+\mathrm{CoCl}_{2}$ group. ${ }^{\# \#} \mathrm{P}<0.01$ vs. the control group; ${ }^{* *} \mathrm{P}<0.01$ vs. the $\mathrm{CoCl}_{2}$ group; ${ }^{\$ \$} \mathrm{P}<0.01$ vs. the $\mathrm{NaHS}+\mathrm{CoCl}_{2}$ group.

well as the apoptotic percentage of PC12 cells compared with the NaHS pretreatment $+\mathrm{CoCl}_{2}$ group $(\mathrm{P}<0.01)$ (Fig. 4B). Additionally, pretreatment of PC12 cells with DHK for $30 \mathrm{~min}$ before $400 \mu \mathrm{M}$ NaHS preconditioning clearly inhibited $\mathrm{H}_{2} \mathrm{~S}$-induced preservation of MMP (Fig. 5). These findings 
A
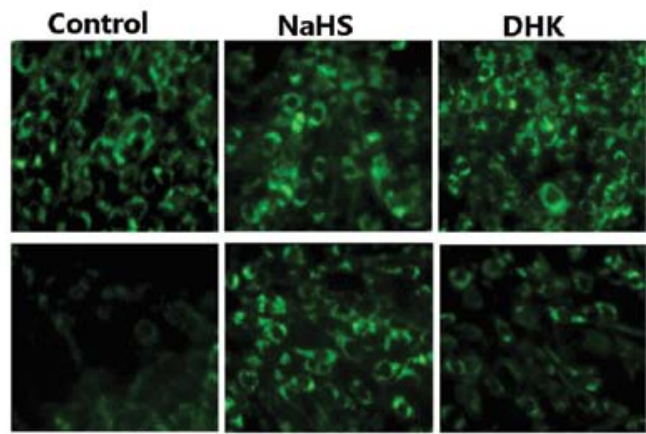

$\mathrm{CoCl}_{2}$

B

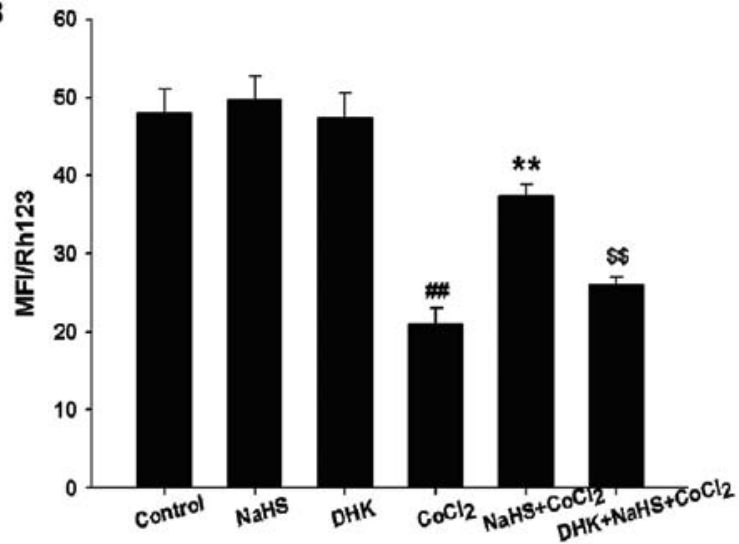

Figure 5. Role of GLT-1 in the cytoprotection of $\mathrm{H}_{2} \mathrm{~S}$ against mitochondrial damage induced by $\mathrm{CoCl}_{2}$ in $\mathrm{PC} 12$ cells. MMP was measured by Rhodamine 123 (Rh123) staining followed by photofluorography. (A) Random micrographs of Rh123-derived fluorescence in PC12 cells. Control group, normal PC12 cells; NaHS group, cells were treated with $400 \mu \mathrm{M}$ NaHS for $30 \mathrm{~min}$ alone; DHK group, cells were treated with $400 \mu \mathrm{M}$ DHK for 30 min alone; $\mathrm{CoCl}_{2}$ group, cells were treated with $600 \mu \mathrm{M} \mathrm{CoCl}_{2}$ for $24 \mathrm{~h} ; \mathrm{NaHS}+\mathrm{CoCl}_{2}$, cells were pretreated with $400 \mu \mathrm{M} \mathrm{NaHS}$ for $30 \mathrm{~min}$ followed by exposure to $600 \mu \mathrm{M} \mathrm{CoCl}_{2}$ for $24 \mathrm{~h}$. DHK $+\mathrm{NaHS}+\mathrm{CoCl}_{2}$ group, cells were pretreated with $400 \mu \mathrm{M}$ DHK for 30 min prior to NaHS preconditioning followed by the same protocols as in the $\mathrm{NaHS}+\mathrm{CoCl}_{2}$ group. (B) Quantitative analysis of the mean fluorescence intensity of Rh123 in each group, performed using Image J 1.410 software. ${ }^{\# \#} \mathrm{P}<0.01$ vs. the control group; ${ }^{* *} \mathrm{P}<0.01$ vs. the $\mathrm{CoCl}_{2}$ group; ${ }^{\$ \$} \mathrm{P}<0.01$ vs. the $\mathrm{NaHS}+\mathrm{CoCl}_{2}$ group.

suggest that GLT-1 contributes to the cytoprotection of $\mathrm{H}_{2} \mathrm{~S}$ against $\mathrm{CoCl}_{2}$-induced injuries.

ROS are involved in the $\mathrm{CoCl}_{2}$-induced downregulation of GLT-1 expression in PC12 cells. Since ROS generation inhibits glutamate uptake function (22), we examined whether ROS is involved in the $\mathrm{CoCl}_{2}$-induced downregulation of GLT-1 protein expression in PC12 cells. Pretreatment of cells with $500 \mu \mathrm{M}$ NAC (a ROS scavenger) for $60 \mathrm{~min}$ prior to exposure to $600 \mu \mathrm{M} \mathrm{CoCl}_{2}$ for $24 \mathrm{~h}$ significantly blocked $\mathrm{CoCl}_{2}$-induced downregulation of GLT-1 expression (Fig. 6). These data indicate that the inhibitory effect of $\mathrm{CoCl}_{2}$ on GLT- 1 expression may be associated with oxidative stress.

Activation of ERK1/2 contributes to the downregulation of GLT-1 expression induced by $\mathrm{CoCl}_{2}$ in $\mathrm{PC} 12$ cells. Stimulation of ERK1/2MAPK also contributes to the inhibition of glutamate uptake (23). In order to investigate the effect of ERK1/2 activation on the downregulation of GLT-1 expression induced by $\mathrm{CoCl}_{2}, \mathrm{PC} 12$ cells were pretreated with $10 \mu \mathrm{M} \mathrm{U} 0126$ (a MEK1/2 inhibitor) for $120 \mathrm{~min}$ prior to treatment with $600 \mu \mathrm{M}$

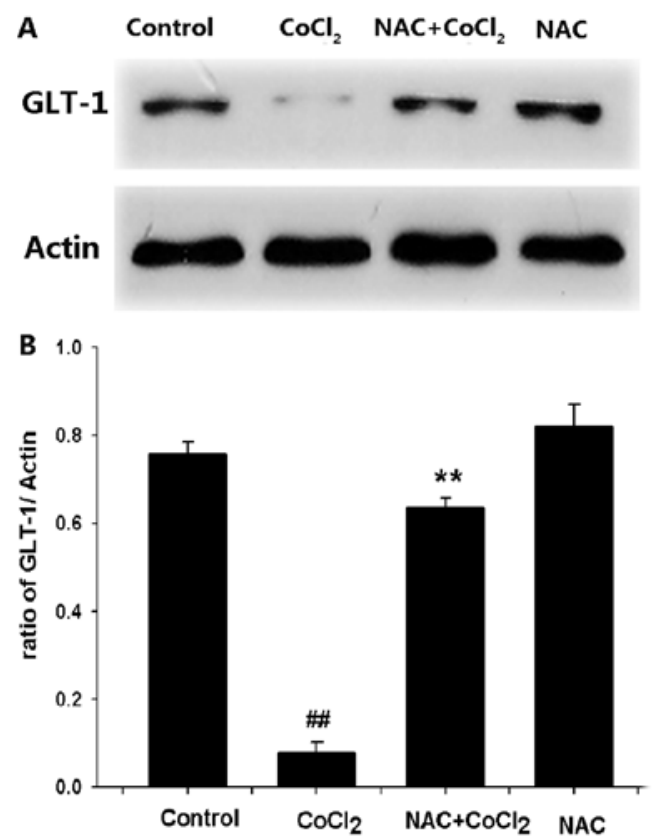

Figure 6. Effect of NAC on the downregulation of GLT-1 expression induced by $\mathrm{CoCl}_{2}$ in PC12 cells. (A) PC12 cells were treated with $600 \mu \mathrm{M} \mathrm{CoCl}_{2}$ for $24 \mathrm{~h}$ in the presence or absence of pretreatment with $500 \mu \mathrm{M}$ NAC for $60 \mathrm{~min}$. (B) Densitometric analysis for the results in (A). ${ }^{\# \prime} \mathrm{P}<0.01$ vs. the control group; ${ }^{* *} \mathrm{P}<0.01$ vs. the $\mathrm{CoCl}_{2}$ group.

$\mathrm{CoCl}_{2}$ for $24 \mathrm{~h}$. U0126 significantly reversed the inhibitory effect of $\mathrm{CoCl}_{2}$ on the expression of GLT- 1 in PC12 cells, suggesting that activation of ERK $1 / 2$ contributes to the downregulation of GLT-1 expression induced by $\mathrm{CoCl}_{2}$ in $\mathrm{PC} 12$ cells (Fig. 2).

\section{Discussion}

GLT-1 has been classified as an astroglial transporter due to its predominant and widespread expression in astrocytes. In the present study, we found that PC12 cells expressed GLT-1, suggesting that GLT-1 may be involved in maintaining a normal level of glutamate in PC12 cells, which is consistent with a previous study (17). It is well known that GLT-1 plays a major role in glutamate re-uptake from the synaptic cleft after neuronal transmission $(6,24,25)$. Lack of GLT-1 has indeed been shown to promote extracellular glutamate accumulation, excitotoxicity and, ultimately, cell death $(26,27)$. GLT-1 has been estimated to represent up to $1 \%$ of total brain protein (6). The expression of GLT-1 is reduced in several animal models of neurodegenerative diseases, including traumatic brain injury (28) and hypoxic/ischemic insults $(16,29)$. The levels of the GLT-1 and/or GLAST protein are also lower in the brain tissue from the patients with Alzheimer's disease (AD) (30) and Huntington's disease (31). The results of the present study showed that $\mathrm{CoCl}_{2}$, a well-known hypoxia mimetic agent, attenuates expression of GLT-1 in a time-dependent manner. Our findings are comparable with a study showing that transient global ischemia reduces GLT-1 expression (16). Similarly, it was reported that GLT-1 protein levels are reduced in the brain in various models of central hypoxia/ ischemia $(16,29,32)$. Under hypoxic conditions $\left(2.5\right.$ and $1 \% \mathrm{O}_{2}$ exposure for $24 \mathrm{~h}$ ), glutamate uptake and GLT-1 protein levels 
are significantly decreased in astrocytes (33). These studies all support our results. By contrast, Kobayashi and Millhorn (17) indicated that exposure of PC12 cells to hypoxia $\left(1 \% \mathrm{O}_{2}\right)$ for 6 to $24 \mathrm{~h}$ increases GLT-1 protein levels. Therefore, it is likely that the effects of hypoxia/ischemia on the expression of GLT-1 may be affected by many factors, including tissue or cell types, the level of hypoxia, manner of hypoxia induction and also the period of hypoxia/ischemia.

To clarify the mechanisms underlying the inhibitory effect of chemical hypoxia on GLT-1 expression, we tested the possible involvement of ROS. Several previous studies have shown that oxidative stress is implicated in glutamate clearance impairment and reduction of GLT-1 expression $(18,21,34)$. Our recent studies have demonstrated the promotive effects of $\mathrm{CoCl}_{2}$ on ROS production $(19,20)$. In this study, we found that NAC, a ROS scavenger, can significantly block the inhibition of GLT-1 expression induced by $\mathrm{CoCl}_{2}$, revealing that ROS partly contribute to the inhibitory effect of chemical hypoxia on the expression of GLT-1 in PC12 cells. We provide novel evidence for the role of $\mathrm{ROS}$ in $\mathrm{CoCl}_{2}$-induced neuronal injury. Additionally, there is currently a lot of data demonstrating that oxidative stress may trigger and modulate the MAPK signaling pathways $(21,35,36)$. We recently demonstrated that ROS can activate the MAPK pathway (20), linking to the possibility of an altered ERK1/2 activation that ultimately affects the expression of GLT-1. To confirm this possibility, we observed the effects of pretreatment of PC12 cells with UO126 (an inhibitor of MEK1/2) on the inhibition of GLT-1 expression by $\mathrm{CoCl}_{2}$. Our results showed that U0126 clearly suppressed the $\mathrm{CoCl}_{2}$-induced decrease in the expression of GLT-1, suggesting that the ERK1/2 pathway is involved in the inhibitory effect of $\mathrm{CoCl}_{2}$ on GLT-1 expression. This is also a novel finding showing that the ROS-activated ERK1/2 pathway plays a role in the inhibition of GLT-1 expression by $\mathrm{CoCl}_{2}$. Our findings are supported by previous studies $(18,35)$. Lu et al (18) reported that PD98059, a specific ERK1/2 inhibitor, significantly reverses the reduction of trafficking of GLT-1 from cytoplasma to plasma membrane.

Although research on the regulatory mechanisms for GLT-1 expression has intensified, scarce data are available regarding the regulatory effect of gasotransmitter on the expression of GLT-1. $\mathrm{H}_{2} \mathrm{~S}$, recently recognized as the third gasotransmitter alongside nitric oxide (NO) and carbon monoxide (CO) (39), has attracted extensive attention due to its multiple physiological and pathophysiological roles in various body systems (18-20,37-41). Kimura and Kimura (38) demonstrated the nueroprotective effect of $\mathrm{H}_{2} \mathrm{~S}$ against oxidative stress-induced injury in primary rat cortical neurons. $\mathrm{H}_{2} \mathrm{~S}$ also protects astrocytes from $\mathrm{H}_{2} \mathrm{O}_{2}$-induced neural injury (18). We recently found that $\mathrm{H}_{2} \mathrm{~S}$ protects $\mathrm{PC} 12$ cells against $\mathrm{CoCl}_{2}$-induced damage by enhancing heat shock protein 90 (HSP90) (19), inhibiting the ROS-activated ERK1/2 and p38MAPK signaling pathways (20) and scavenging ROS (19,20). In the present study, we provide evidence for the first time that NaHS (a donor of $\mathrm{H}_{2} \mathrm{~S}$ ) pretreatment prevents the $\mathrm{CoCl}_{2}$-induced downregulation of GLT-1 expression in PC12 cells. Our results are in line with a recent study that $\mathrm{H}_{2} \mathrm{~S}$ protects astrocytes against oxidative stress-induced neural damage by increasing glutamate uptake (18). Based on our recent results $(19,20,39-41)$ and other studies $(18,21,35,36,38,42)$, there are several possible mechanisms responsible for the regulatory effect of $\mathrm{H}_{2} \mathrm{~S}$ on the expression of GLT-1: i) its antioxidation, by which $\mathrm{H}_{2} \mathrm{~S}$ can protect $\mathrm{PC} 12$ cells from $\mathrm{CoCl}_{2}$-induced suppression of GLT-1 expression; ii) its inhibitory effect on the ERK1/2 pathway (20); and iii) $\mathrm{H}_{2} \mathrm{~S}$ functions as an ATP-sensitive potassium $\left(\mathrm{K}_{\mathrm{ATP}}\right)$ channel opener (43). Hu et al (42) indicated that iptakalim, a $\mathrm{K}_{\mathrm{ATP}}$ channel opener, can reverse the inhibition of glutamate uptake induced by N-methyl-4-4-phenylpyridinium $\left(\mathrm{MPP}^{+}\right)$[used to stimulate Parkinson's disease (PD)-like conditions], revealing a role of the $\mathrm{K}_{\mathrm{ATP}}$ channel opener in the functional regulation of glutamate transporter. Further research is required to confirm these findings.

We further explored the role of GLT-1 in the neuroprotection of $\mathrm{H}_{2} \mathrm{~S}$ against chemical hypoxia-induced injury. We found that pretreatment with DHK, a selective inhibitor of GLT-1, significantly reversed the protective effect of $\mathrm{H}_{2} \mathrm{~S}$ against $\mathrm{CoCl}_{2}$-induced injuries, evidenced by a decrease in cell viability and an increase in apoptotic PC12 cells as well as MMP loss, suggesting that upregulation of GLT-1 expression may play an important role in the neuroprotective effects of $\mathrm{H}_{2} \mathrm{~S}$.

In summary, in the present study, we have demonstrated for the first time that: i) both ROS and the ERK1/2 pathway contribute to the downregulation of GLT-1 expression induced by $\mathrm{CoCl}_{2}$; ii) $\mathrm{H}_{2} \mathrm{~S}$, a novel gaseous neuromodulator, reverses $\mathrm{CoCl}_{2}$-induced downregulation of GLT-1 expression; and iii) upregulation of GLT-1 expression may play a crucial role in the neuroprotective effects of $\mathrm{H}_{2} \mathrm{~S}$ against chemical hypoxiainduced neuronal injury in PC12 cells. The findings of the present study may provide a potential neuroprotective therapeutic approach for treatment of hypoxia/ischemia-related neuronal injury. In addition, based on the notable findings that both levels of endogenous $\mathrm{H}_{2} \mathrm{~S}$ and GLT-1 are reduced in neurodegenerative diseases, such as $\mathrm{AD}$ and $\mathrm{PD}$, we speculate that endogenous $\mathrm{H}_{2} \mathrm{~S}$ may be an important modulator of GLT-1. These findings remain to be confirmed in future studies.

\section{Acknowledgements}

The present study was supported by the Guangdong Science and Technology Planning project (nos. 2010B080701105, 2009B080701014 and 2007B080701030).

\section{References}

1. Nilsson GE and Lutz PL: Release of inhibitory neurotransmitters in response to anoxia in turtle brain. Am J Physiol 261: R32-R37, 1991.

2. Richter DW, Lalley PM, Pierrefiche O, et al: Intracellular signal pathways controlling respiratory neurons. Respir Physiol 110: 113-123, 1997.

3. Nicholls D and Attwell D: The release and uptake of excitatory amino acids. Trends Pharmacol Sci 11: 462-468, 1990.

4. Rothman SM and Olney JW: Glutamate and the pathophysiology of hypoxic - ischemic brain damage. Ann Neurol 19: 105-111, 1986.

5. Sattler R, Xiong Z, Lu WY, et al: Distinct roles of synaptic and extrasynaptic NMDA receptors in excitotoxicity. J Neurosci 20: 22-33, 2000.

6. Lehre KP and Danbolt NC: The number of glutamate transporter subtype molecules at glutamatergic synapses: chemical and stereological quantification in young adult rat brain. J Neurosci 18: 8751-8757, 1998

7. Tanaka K: Expression cloning of a rat glutamate transporter. Neurosci Res 16: 149-153, 1993. 
8. Attwell D, Barbour B and Szatkowski M: Nonvesicular release of neurotransmitter. Neuron 11: 401-407, 1993.

9. Kanai Y, Smith CP and Hediger MA: A new family of neurotransmitter transporters: the high-affinity glutamate transporters FASEB J 7: 1450-1459, 1993.

10. Anderson CM and Swanson RA: Astrocyte glutamate transport: review of properties, regulation, and physiological functions Glia 32: 1-14, 2000

11. Gegelashvili $\mathrm{G}$ and Schousboe A: High affinity glutamate transporters: regulation of expression and activity. Mol Pharmacol 52: 6-15, 1997.

12. Phillis JW, Ren $\mathbf{J}$ and $\mathrm{O}^{\prime}$ Regan $\mathrm{MH}$ : Transporter reversal as a mechanism of glutamate release from the ischemic rat cerebral cortex: studies with DL-threo-beta-benzyloxyaspartate. Brain Res 868: 105-112, 2000.

13. Rao VLR, Dogan A, Todd JG, et al: Antidense knockdown of the glial glutamate transporter GLT-1, but not the neuronal glutamate transporter EAAC1, exacerbates transient focal cerebral ischemiainduced neuronal damage in rat brain. J Neurosci 21: 1876-1883, 2001.

14. Zhang G, Raol YS, Hsu FC and Brooks-Kayal AR: Long-term alterations in glutamate receptor and transporter expression following early-life seizures are associated with increased seizure susceptibility. J Neurochem 88: 91-101, 2004.

15. Mimura K, Tomimatsu T, Minato K, et al: Ceftriaxone preconditioning confers neuroprotection in neonatal rats through glutamate transporter 1 upregulation. Reprod Sci 18: 1193-1201, 2011.

16. Raghavendra Rao VL, Rao AM, Dogan A, et al: Glial glutamate transporter GLT-1 downregulation precedes delayed neuronal death in gerbil hippocampus following transient global cerebral ischemia. Neurochem Int 36: 531-537, 2000.

17. Kobayashi S and Millhorn DE: Hypoxia regulates glutamate metabolism and membrane transport in rat PC12 cells J Neurochem 76: 1935-1948, 2001.

18. $\mathrm{Lu} \mathrm{M}, \mathrm{Hu} \mathrm{LF}, \mathrm{Hu} \mathrm{G}$ and Bian JS: Hydrogen sulfide protects astrocytes against $\mathrm{H}_{2} \mathrm{O}_{2}$-induced neural injury via enhancing glutamate uptake. Free Radic Biol Med 4: 1705-1713, 2008.

19. Meng JL, Mei WY, Dong YF, et al: Heat shock protein 90 mediates cytoprotection by $\mathrm{H}_{2} \mathrm{~S}$ against chemical hypoxiainduced injury in PC12 cells. Clin Exp Pharmacol Physiol 38 42-49, 2011.

20. Lan A, Liao X, Mo L, et al: Hydrogen sulfide protects against chemical hypoxia-induced injury by inhibiting ROS-activated ERK1/2 and p38MAPK signaling pathways in PC12 cells. PLoS One 6: e25921, 2011.

21. Matos M, Augusto E, Oliveira CR and Agostinho P: Amyloidbeta peptide decreases glutamate uptake in cultured astrocytes: involvement of oxidative stress and mitogen-activated protein kinase cascades. Neuroscience 156: 898-910, 2008.

22. Sun XL, Zeng XN, Zhou F, et al: K(ATP) channel openers facilitate glutamate uptake by GluTs in rat primary cultured astrocytes. Neuropsychopharmacology 33: 1336-1342, 2008.

23. Figiel M, Maucher T, Rozyczka J, et al: Regulation of glial glutamate transporter expression by growth factors. Exp Neurol 183: 124-135, 2003

24. Lehre KP, Levy LM, Ottersen OP, et al: Differential expression of two glial glutamate transporters in the rat brain: quantitative and immunocytochemical observations. J Neurosci 5: 1835-1853, 1995.

25. Kugler P and Schmitt A: Glutamate transporter EAAC1 is expressed in neurons and glial cells in the rat nervous system. Glia 27: 129-142, 1999.
26. Tanaka K, Watase K, Manabe T, et al: Epilepsy and exacerbation of brain injury in mice lacking the glutamate transporter GLT-1. Science 276: 1699-1702, 1997.

27. Vorwerk CK, Naskar R, Schuettauf F, et al: Depression of retinal glutamate transporter function leads to elevated intravitreal glutamate levels and ganglion cell death. Invest Ophthalmol Vis Sci 41: 3615-3621, 2000

28. Rao VL, Baskaya MK, Doğan A, et al: Traumatic brain injury downregulates glial glutamate transporter (GLT-1 and GLAST) proteins in rat brain. J Neurochem 70: 2020-2027, 1998

29. Torp R, Lekieffre D, Levy LM, et al: Reduced postischemic expression of a glial glutamate transporter, GLT1, in the rat hippocampus. Exp Brain Res 103: 51-58, 1995.

30. Li S, Mallory M, Alford M, Tanaka S and Masliah E: Glutamate transporter alterations in Alzheimer disease are possibly associated with abnormal APP expression. J Neuropathol Exp Neurol 56: 901-911, 1997.

31. Lipton SA and Rosenberg PA: Excitatory amino acids as a final common pathway for neurologic disorders. N Engl J Med 330: 613-622, 1994

32. Martin LJ, Brambrink AM, Lehmann C, et al: Hypoxia-ischemia causes abnormalities in glutamate transporters and death of astroglia and neurons in newborn striatum. Ann Neurol 42: 335-348, 1997.

33. Dallas M, Boycott HE, Atkinson L, et al: Hypoxia suppresses glutamate transport in astrocytes. J Neurosci 27: 3946-3955, 2007.

34. Brera B, Serrano A and de Ceballos ML: beta-amyloid peptides are cytotoxic to astrocytes in culture: a role for oxidative stress. Neurobiol Dis 7: 395-405, 2000.

35. McCubrey JA, Lahair MM and Franklin RA: Reactive oxygen species-induced activation of the MAP kinase signaling pathways. Antioxid Redox Signal 8: 1775-1789, 2006.

36. Zhu X, Lee HG, Raina AK, et al: The role of mitogen-activated protein kinase pathways in Alzheimer's disease. Neurosignals 11: 270-281, 2002.

37. Wang R: The gasotransmitter role of hydrogen sulfide. Antioxid Redox Signal 5: 493-501, 2003.

38. Kimura Y and Kimura $\mathrm{H}$ : Hydrogen sulfide protects neurons from oxidative stress. FASEB J 18: 1165-1167, 2004.

39. Yang Z, Yang C, Xiao L, et al: Novel insights into the role of HSP90 in cytoprotection of $\mathrm{H}_{2} \mathrm{~S}$ against chemical hypoxiainduced injury in $\mathrm{H} 9 \mathrm{c} 2$ cardiac myocytes. Int $\mathrm{J}$ Mol Med 28: 397-403, 2011.

40. Chen SL, Yang CT, Yang ZL, et al: Hydrogen sulphide protects $\mathrm{H} 9 \mathrm{c} 2$ cells against chemical hypoxia-induced injury. Clin Exp Pharmacol Physiol 37: 316-321, 2010.

41. Yang CT, Yang ZL, Zhang MF, et al: Hydrogen sulfide protects against chemical hypoxia-induced cytotoxicity and inflammation in $\mathrm{HaCaT}$ cells through inhibition of $\mathrm{ROS} / \mathrm{NF} \kappa \mathrm{B} / \mathrm{COX}-2$ pathway. PLOS One 6: e21971, 2011

42. Hu LF, Wang S, Shi XR, et al: ATP-sensitive potassium channel opener iptakalim protected against the cytotoxicity of MPP on SH-SY5Y cells by decreasing extracellular glutamate level. J Neurochem 94: 1570-1579, 2005.

43. Johansen D, Ytrehus K and Baxter GF: Exogenous hydrogen sulfide $\left(\mathrm{H}_{2} \mathrm{~S}\right)$ protects against regional myocardial ischemiareperfusion injury - evidence for a role of $\mathrm{K}_{\mathrm{ATP}}$ channels. Basic Res Cardiol 101: 53-60, 2006. 